\title{
Molecular and Immunological Methods to Confirm Toxiginicity (Microcystin Production) of Westiellopsis Prolifica Isolated from Tigris River - Iraq
}

Ibrahim Jabber Abed ${ }^{1 *}$

Ghusoon Ali Abdulhasan ${ }^{1}$

Laith Ibrahim Moushib ${ }^{2}$

\author{
Received 2/9/2018, Accepted 24/4/2019, Published 18/12/2019
}

This work is licensed under a Creative Commons Attribution 4.0 International License.

\begin{abstract}
:
Several toxigenic cyanobacteria produce the cyanotoxin (microcystin). Being a health and environmental hazard, screening of water sources for the presence of microcystin is increasingly becoming a recommended environmental procedure in many countries of the world. This study was conducted to assess the ability of freshwater cyanobacterial species Westiellopsis prolifica to produce microcystins in Iraqi freshwaters via using molecular and immunological tools. The toxigenicity of $W$. prolifica was compared via laboratory experiments with other dominant bloom-forming cyanobacteria isolated from the Tigris River: Microcystis aeruginosa, Chroococcus turigidus, Nostoc carneum, and Lyngbya sp. significant expression of $m c y E$ gene and microcystin production was most evident in $W$. prolifica. Contrary to the prevailing concept that $M$. aeruginosa is a main microcystin producer in freshwaters around the world, no significant microcystin production was observed with this species throughout the time points studied in our laboratory methods. As for $C$. turigidus, $N$. carneum and Lyngbya sp., neither mcyE expression nor microcystin production was significant. Data from $m c y E$ expression by RT-qPCR were generally in agreement with those obtained from microcystin quantification by ELISA. Interestingly, W. prolifica, which showed clear microcystin-producing ability in this study and which was not reported before in the literature to produce microcystin, can be added as a new microcystin producer to the list of toxigenic cyanobacteria.
\end{abstract}

Key words: Cyanobacteria, ELISA, Microcystin, Tigris River, Westiellopsis prolifica.

\section{Introduction:}

Around the world, freshwaters are considered as a main source of drinking water to the large number of peoples. Cyanobacterial blooms represent a nuisance to water environmental monitoring bodies for a number of reasons. In addition to the production of persistent unpleasant odors in waters that can deteriorate water quality (e.g., Geosmin), toxin production by cyanobacteria in surface waters poses a serious environmental and health concern due to its direct relation to both human and animal health $(1,2)$. Cyanobacteria are known to produce several types of toxins like microcystins, nodularins, cylindrospermopsin, anatoxins and saxitoxins $(3,4)$. Microcystins are the only toxins that have set standards by the World Health Organization in drinking and recreational water and are the only cyanotoxins screened for by municipal management agencies (5).

\footnotetext{
${ }^{1}$ Department of Biology, College of Science, University of Baghdad, Baghdad, Iraq.

${ }^{2}$ Department of Biology/ Lund University, Sölvegatan 35, 22362 Lund, Sweden.

*Correspondence: ibrahimabed95@yahoo.com
}

A number of environmental factors, like hot and long summers and recurrent water pollution was lead to the formation of blooms. Several studies conducted to investigate water safety in a number of Middle Eastern countries confirmed the presence of cyanotoxins in common water sources. For example, toxigenic cyanobacteria and cyanotoxin production (microcystin and other toxins) were found in different Arabic freshwater sources from Tunisia (6), Egypt (7), Saudi Arabia (8) and Iraq (9, $10,11,12)$. However, despite the high incidence of water pollution and favorable environmental conditions for bloom formation in many Arabic countries, environmental and health authorities in these countries rarely consider cyanobacterial blooms as an environmental concern that necessitates mandatory periodic water testing (for possible toxin production) by water treatment stations and Iraq is no exception.

The Tigris, one of the two main rivers of Iraq, divides Baghdad into two parts: the eastern part is called Al-Risafa and the western part is called Al-Karkh. The river suffers from recurrent eutrophic events due to industrial and domestic discharge. Our previous work (10) in other parts of 
Baghdad demonstrated the existence of the microcystin gene mcyE in Westiellopsis prolifica and other species using conventional PCR. To date, nothing is known about the toxigenicity of common bloom-forming cyanobacterial species in Iraqi freshwaters. Therefore, this study was designed to analyze and compare the toxigenicity of common bloom-forming cyanobacteria found in the Tigris. Our study is the first to clearly and conclusively document the in vitro microcystin production in $W$. prolifica (that belongs to the order Nostocales) using confirmatory molecular and immunological methods.

\section{Materials and Methods: \\ Collection and preparation of samples}

Water samples were collected from the main intake of the Tigris River from May to September 2014 from two geographically different locations (the first was located at North of Baghdad in Sader AlQanat whereas the second site was at the middle part in Al-Jadiryia area) where events of blooming were known to be commonly occurring in these locations. Phytoplankton samples were collected from the higher superficial layer with 20$30 \mathrm{~cm}$ deep from the intake of river in the amount of two samples, one for isolation solution and the second for cyanobacterial identification by using Lugol's solution was added to the collected water sample. The collection method was performed by using phytoplankton net $20 \mu$ in mesh. Samples were transported to the lab directly and incubated under suitable and controlled conditions for algal growth $\left(200 \mu \mathrm{E} / \mathrm{m}^{2} / \mathrm{s}\right.$ and $\left.26 \pm 2 \mathrm{C}^{\circ}\right)$.

\section{Culturing of cyanobacteria and microscopic examination}

The uni-algal culture of cyanobacterial species was obtained by using serial dilution method (13). Serial dilutions from the collected samples were prepared starting with $1 \mathrm{ml}$ of sample inoculated into $9 \mathrm{ml}$ of BG11 nutrient solution. This procedure was repeated with examining each dilution until one species of algae was obtained. Uni-algal cultures were observed under microscopie; the cell shape and size were monitored. The isolated phytoplankton were grown in sterilized BG-11 growth medium in $250 \mathrm{ml}$ flasks. The cultures were incubated in a controlledenvironment cabinet at $25 \pm 0.5 \mathrm{C}^{\circ}$ with cool white fluorescent lights $\left(\left(200 \mu \mathrm{E} / \mathrm{m}^{2} / \mathrm{s}\right.\right.$ and $26 \pm 2,12 \mathrm{~h}$ light/12 $\mathrm{h}$ dark). Microscopic examination was performed on the glutaraldehyde-fixed samples using a Zeiss Axiovert 200 light microscope equipped with interference contrast. The morphological identification of cyanobacteria was done according to Desikachary (14). The optical density was measured for initial inoculum of all isolated algae and unified to 0.02 O.D.

\section{DNA extraction from cultures of isolated cyanobacterial species}

Genomic DNA was extracted from nearly $100 \mathrm{mg}$ ww. for each cultured cyanobacterial species as follows: cells were lyzed mechanically by bead beating with a Fast Prep 24 instrument (Mpbio) at speed 5.5 for $60 \mathrm{sec}$. The DNA was subsequently extracted using the Bio Ready Genomic DNA miniprep kit in accordance with the manufacturer's instructions (Miclab Biotech/China). Concentrations and purity of DNA were determined using a Nano drop ND-2000 spectrophotometer (Thermo scientific, USA) (15).

\section{Amplification of $m c y E$ gene by PCR}

Relying on the estimation of $m c y E$ copy numbers, it is potential to quantify $m c y E$ expression in cyanobacterial isolates by preparing external standards. These standards were prepared from the PCR products performed on the DNA samples from the cyanobacterial species using the primer pair HEPF 5'-TTTGGGGTTAACTT TTTTGGGCATAGTC-3' and HEPR 5'AATTCTTGAGGCTGTAAATCGGGTTT-3' (16). After several trials of optimization, the reaction mixture was carried out in $20 \mu 1$ including $5 \mu 1$ of PCR premix (Bionear, Korea), $2 \mu \mathrm{l}$ of DNA template and $1 \mu \mathrm{l}$ of each primer ( 2 picomole/ $\mu \mathrm{l})$, the volume was completed with distilled water. The PCR protocol was done in Master cycler gradient PCR (Eppendroff, Germany) involving one cycle for $2 \mathrm{~min}$ at $95{ }^{\circ} \mathrm{C}, 35$ cycles for $90 \mathrm{sec}$ at $95{ }^{\circ} \mathrm{C}, 90$ sec at $59{ }^{\circ} \mathrm{C}, 60 \mathrm{sec}$ at $72{ }^{\circ} \mathrm{C}$ and a final one cycle for $8 \mathrm{~min}$ at $72{ }^{\circ} \mathrm{C}$.

\section{Subcloning of PCR products into pMID18-T vector}

The PCR products from the amplification of $m c y E$ using HEPF/R primer set were excised from the gel and purified using Biospin Gel Extraction kit (Biospin,China) according to the manufacturer's instructions. The DNA concentration was measured on the Nanodrop and the PCR fragments were subcloned into the TA cloning vector PMID18-T (TakaRaBiotechnoloy,China) by mixing the DNA insert/plasmid in a ratio of 4:1 and transformed into Cacl2-competent E. coli (DH5 $\alpha) .10 \mu \mathrm{l}$ of the ligation mixture were used for transforming $E$. coli DH5 $\alpha$ via calcium chloride method. Positive transformants were screened using LB plates supplemented with $100 \mu \mathrm{g} / \mathrm{ml}$ ampicillin. The plasmid DNA (mcyE-pMID18-T DNA) from the transformed E.coli cell was isolated using the Easy Pure plasmid miniprep kit ${ }^{\mathrm{TM}}$ (TransCan 
Biotechnology, China) according to the manufacturer's instructions. After isolating the mcyE-pMID18-T DNA, the presence of the DNA inserted in the pMID18-T vector and its right sequencing of the vector using the Prism Big Dye cycle-sequencing system ABI 37030 DNA analyzer sequencer (Applied Biosystem, USA) (17).

\section{Primer design}

The sequenced $m c y E$ products from the Toxogenic cyanobacterial species were identified using BLAST/NCBI data and used to design a new primer pair (hema 2): hema2F 5'TGGCGAGGAAGTAGGAACAG-3'/ hema2R 5'AATCGGGTTTACGGC TCTG-3'. Forq PCR and RT-qPCR experiments with the help of the Beacon designer software. The hema 2 primer set (ordered from Sangon Biotech, China) was tested for specificity by BLAST search.

\section{Preparation of standard curve}

Quantitative real-time PCR assay (qPCR) was used for testing the newly designed primers (hema 2) and to prepare the absolute standard curve used for estimating $m c y E$ gene copy number.In order to quantify the copy number of the $m c y E$ genes, a ten-fold dilution series $\left(10^{2}-10^{7}\right.$ copy/ $\left.\mu \mathrm{l}\right)$ from the linearized plasmid DNA (mcyE-PMD18-T vector) was generated by correlating the gene copy number and the threshold cycle $(\mathrm{Ct})$ values (Figure. $2)$. The quantity of the target DNA $(m c y E)$ was determined according to formula used by Vaitomaa et al. (18).

\section{RNA extraction}

The RNA was extracted from cyanobacterial isolates at four different periods of growth (zero, one, two and three weeks) using the trizol plus kit (Miclab Biotech, China) according to the instructions of manufacturer's. Cell density was estimated at OD750nm. $1 \mathrm{ml}$ from the unialagal culture from each cyanobacterial species was added to $250 \mathrm{ml}$ of BG11 and this was considered as zero time. The total RNA was converted into cDNA using reverse-transcriptase kit (TaKaRa, Japan). The protocol of real-time PCR was carried out using a two-step process. Residual gDNA with RNA was destroyed with Dnase wipeout buffer prior to RT. A total of $100 \mathrm{ng}$ of purified RNA was reverse transcribed using the QuantiTech ${ }^{\circledR}$ reverse transcription kit (Qiagen Inc.) following the kit manufacturer's protocol. The cDNA concentration and integrity were checked with ND1000 spectrophotometer.
Analysis of gene (mcyE) expression by RT-qPCR

RT-qPCR was used for expression of $m c y$ Egene. The thermal programme include: $2 \mathrm{~min}$. at $50{ }^{\circ} \mathrm{C}, 3 \mathrm{~min}$. at $95{ }^{\circ} \mathrm{C}$, then 40 cycles of $15 \mathrm{sec}$. at $95{ }^{\circ} \mathrm{C}$ and $30 \mathrm{sec}$. at $57{ }^{\circ} \mathrm{C}$, and $72{ }^{\circ} \mathrm{C}$ for two min. qPCR mixture was carried out in $25 \mu$ l using SYBR green real time PCR mastermix (ToyoBo, Japan), $100 \mathrm{ng} / \mu \mathrm{l}$ of cDNA for gene expression assays and 1 pmol of each primer (hema 2). The reaction was carried out in ABI prism 7500 real time PCR (Applied biosystem, USA). Reactions were run at least twice with triplicate samples to ensure the reliability. The amplification efficiency was calculated as the average of all replicates. Melting curve analysis was performed after amplification steps to confirm the correct qPCR product and no non-specific products were formed (18).

\section{Analysis and quantification of microcystin by ELISA technique}

The concentration of microcystin was determined intracellulary and extracellulary by indirect ELISA Kits from cyanobacterial species. Algal samples were prepared according to the method described by Lei et al. (19). Briefly, five isolates of cyanobacteria were cultured on BG11 nutrient solution and were filtered and harvested at first and second week of growth. The harvested cells (from the filtration) were broken by sonication for $10 \mathrm{~min}$ then the debris was removed by centrifugation at $10000 \mathrm{xg}$ for $10 \mathrm{~min}$. The resulting supernatants were used for intracellular assessment of microcystin by ELISA kit (Enzo Life Science Inc., USA). As for the estimation of the concentration of the extracellular fraction of MC (that is released from cells into the culture medium), the filtrate (the liquid fraction from filtering the harvested cells), was used for extracellular assessment of microcystin. Microcystin concentrations were expressed as $\mathrm{ng} / \mathrm{ml}$.

\section{Statistical analysis}

All data were analyzed using the SPSSIBM program (Version-20). The least significant differences (LSD) were used to compare toxin quantities of multiple periods of growth for different cyanobacteria. Also, T-test and MannWhitney test analysis were used to analyze the role of the growth period on extracellular and intracellular toxin production while the frequencies were checked by applying Pearson test to estimate the relative correlation between quantities of toxin produced exracellularly and intracellularly and between quantities of toxin measured by RT-qPCR and ELISA assay. The significant differences were done under probability level $(\mathrm{p} \leq 0.05)$. 


\section{Results and Discussion:}

Microscopic identification of cyanobacteria

According to morphological characteristics of cyanobacteria mentioned in Desikachary (14), the studied isolates were identified as M. aeruginosa, $C$. turigidus, Lyngbya sp., W. prolifica and N. carneum (Fig. 1).

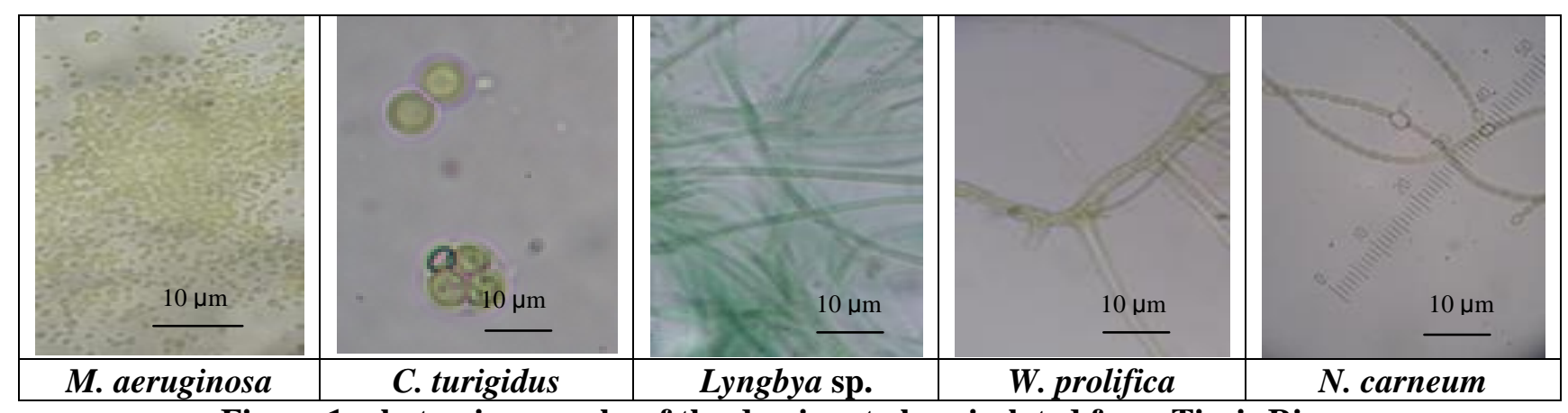

Figure 1. photomicrographs of the dominant algae isolated from Tigris River.

Westiellopsis prolifica Janet 1941

Eupri: Prokaryota

Kingdom: Ebacteria

Sub Kingdom: Negibacteria

Phylum: Cyanobacteria

Class: Cyanophyceae

Sub Class: Nostocophycidae

Order: Nostocales

Family: Hapalosiphonaceae
Genus: Westiellopsis

Species: prolifica

New primer set 'hema 2' was used in qPCR and RT-qPCR experiments

DNA was extracted from the five unialgal cultures of the dominant cyanobacterial species. All the tested species produced a PCR product of $472 \mathrm{bp}$ that was detected in their DNA, which indicated that they harbored the $m c y E$ (Fig.2).

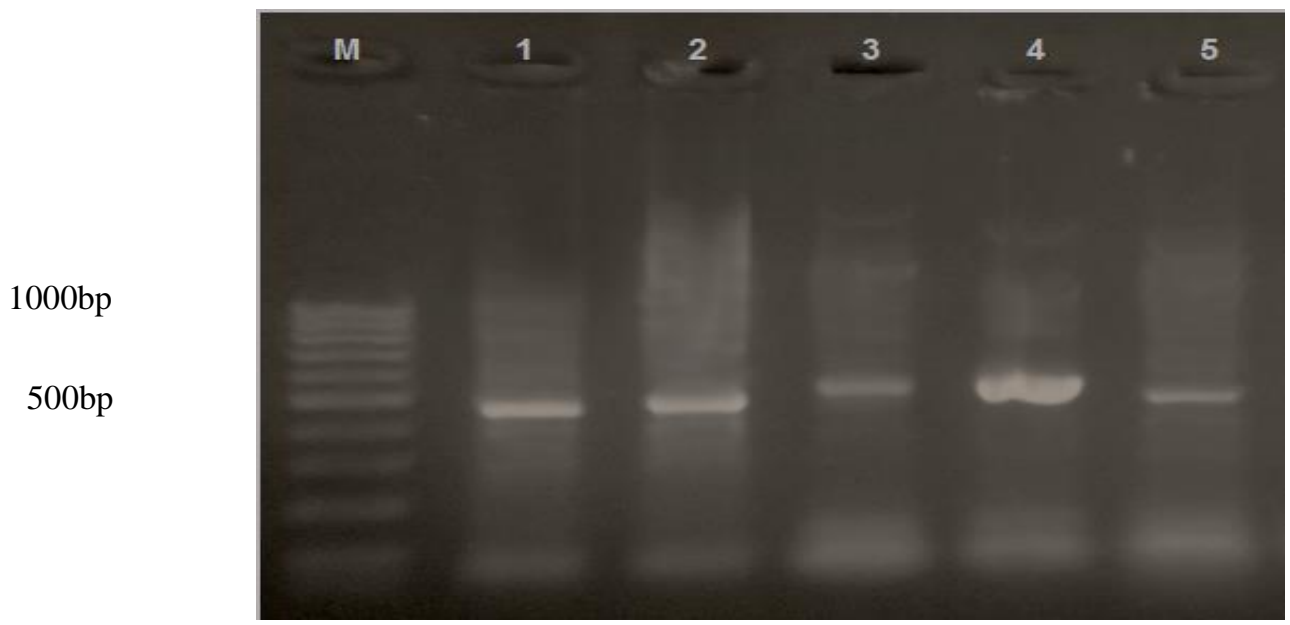

Figure 2. Gel electrophoresis of PCR-amplified microcystin gene mcyE (472bp) in cyanobacterial isolates. Agarose gel $(1.5 \%)$ was run on $75 \mathrm{~V} / \mathrm{cm}$ for 45 minutes, stained with ethidum bromide and visualized on a UV transilluminator. The figure shows results for 1-M. aeruginosa,2- $C$. turigidus,3Lyngbya sp.,4-W. prolific and 5- N. carneum

The PCR products amplified from $m c y E$ (using HEPF/R primer) were sequenced, based on the DNA sequence; the new primer set (hema 2) was designed using the Beacon designer software. The BLAST search of the sequenced $m c y E$ fragments, from all the five cyanobacterial species, exhibited high similarity to other $m c y E$ sequences at the database, all sequences showed $100 \%$ identity except Lyngbya sp. which showed $99 \%$ to other sequences because the selected region was common in all studied algae's. These fragments (shared among all the isolates studied) were chosen for designing hema 2 primer to give an amplicon of 102 bp from DNA/cDNA. hema $2 \mathrm{~F} / \mathrm{R}$ primer showed high specificity for $m c y E$ gene in studied isolates when searched via BLAST.

Furthermore, standard curve derived from the six serial dilutions $\left(10^{2}-10^{7}\right.$ copy/ $\left.\mu \mathrm{l}\right)$ of the linearized plasmid DNA (mcyE-PMD18-T vector) using this set of primer yielded high efficiency reached $92 \%$ with high correlation coefficient (r $=0.99$ ) (Fig.3). Also, performing dissociation 
analysis for hema2 primer showed non-specific PCR products or primer dimer and no signal was found in the negative control samples.

Hema 2 primers successfully amplified the target gene and quantified its copies. Therefore, designing primers from sequencing the $m c y E$ region from the studied cyanobacteria provides a convenient tool for the real assessment of these cyanobacteria as mentioned in the study by Fortin et al. (20)., which noted that primer design is a critical step in the development of qPCR for analysis of cyanobacteria.

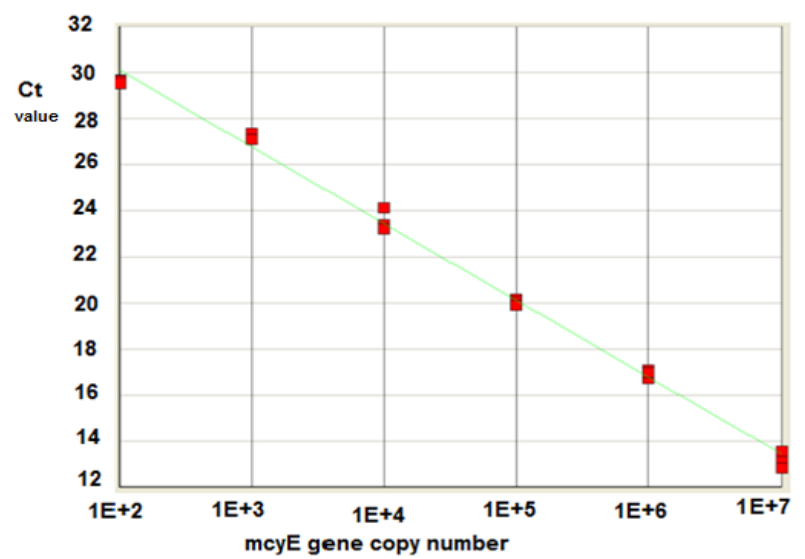

Figure 3. Amplification plot of standard curve prepared to quantify the copy number of the $m c y E$. $\mathrm{X}$-axis shows the six serial concentrations

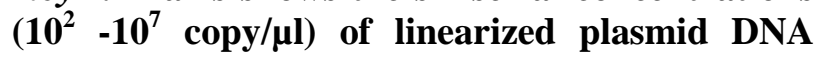
(mcyE-PMD18-T vector) and $\mathrm{Y}$-axis represents the cycle number. The curve yielded high efficiency $(92 \%)$ with high correlation coefficient $\left(r^{2}=0.99\right)$.

\section{Quantification of $m c y E$ expression by RT-qPCR}

The cDNA from studied organisms was successfully amplified using hema 2 primer, while negative controls did not produce any amplicon. RT-qPCR technique was used to quantify the expression of $m c y E$ in the studied cyanobacteria relying on the estimation of the gene copy numbers that could be calculated from the standard curve. For W. Prolifica, there was highly significant expression of $m c y E$ at zero time compared to the same time point with the other species. The expression increased significantly $(\mathrm{P} \leq 0.01)$ at the $1^{\text {st }}$ week (18.8 folds) but decreased notably at the $2^{\text {nd }}$ and $3^{\text {rd }}$ week $(\mathrm{P} \leq 0.01)$ (Fig.4).

Interestingly, $W$. prolifica showed the highest expression level of $m c y E$ when compared to the other studied cyanobacteria $(\mathrm{P} \leq 0.01)$. On the other hand, although very little expression of $m c y E$ was noticed in algal species $C$. turigidus, $N$. carneum and Lyngbya sp. At the time points studied (zero time, $1^{\text {st }}, 2^{\text {nd }}$, and $3^{\text {rd }}$ week), the expression was non-significant differences $(P \geq 0.05)$ in all the time points of study. As for $M$. aeruginosa, there was non-significant expression of $m c y E$ at zero time, $1^{\text {st }}$ and $2^{\text {nd }}$ week. However, the expression increased significantly $(\mathrm{P} \leq 0.01)$ at the $3^{\text {rd }}$ week of growth (190 thousands folds increase) in comparison to the earlier times of the growth. There researchers investigated relationships between the proportion of mcy-genotypes in the population of cyanobacteria and the concentrations of microcystins in waters (21).

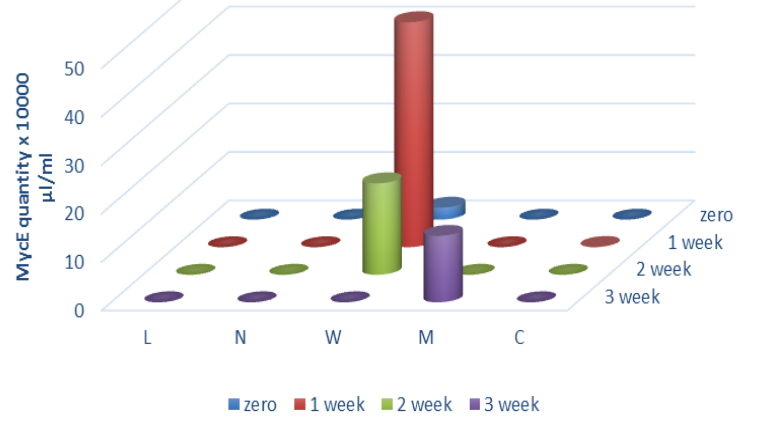

Figure 4. McyE expression from the five cyanobacterial species in different time points (zero, $1^{\text {st }}$ week, $2^{\text {nd }}$ week, and $3^{\text {rd }}$ week). The quantity of mcyE (measured by Rt-qPCR) is

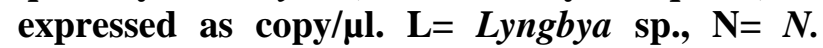
carneum, $\mathrm{W}=W$. prolifica, $\mathrm{M}=M$. aeruginos $a$ and $\mathrm{C}=$ C. turigidus.

W. prolific belongs to Nostocales, an order that includes species commonly found in tropical, subtropical and thermophilic habitats (22). In a recent study, several clusters of non-ribosomal peptide synthesis and polyketide biosynthesis have been found when mining the complete genome of $W$. prolifica which are essential for microcystins and nodularins synthesis (23).

\section{Microcystin ELISA analysis}

Extracellular and intracellular microcystin produced by studied cyanobacterial species during two weeks of growth were determined using ELISA assay. In general (with some exceptions), the quantity of the produced microcystin increased with the period of time. However, in all the species tested, except for $W$. prolifica, toxin production (whether intracellular or extracellular) was nonsignificant (Fig. 5). As for W. prolifica, toxin production (both intracellular and extracellular) was significant $(\mathrm{P} \leq 0.01)$ compared with data from other species. Extracellular microcystin production increased from the first week from $243 \mathrm{ng} / \mathrm{ml}$ to 682 $\mathrm{ng} / \mathrm{ml}$ on the second week. As for the intracellular microcytin production, on the first week it was 377 $\mathrm{ng} / \mathrm{ml}$ and then it decreased on the second week to reach $292.76 \mathrm{ng} / \mathrm{ml}$. Although decreased notably, the microcystin concentration on the $2^{\text {nd }}$ week for 
W. prolifica is still higher when compared with the $2^{\text {nd }}$ week data from other species. Taken together, $W$. prolifica exhibited the most abundant microcystin production and this was in agreement with the gene expression data from RT-qPCR assay. The results showed that the studied growth periods had a significant role $(\mathrm{P} \leq 0.05)$ with quantity of microcystin produced for $W$. prolifica. There was a significant correlation between extracellular microcystin produced on the first and second week ( $\mathrm{P} \leq 0.05, \mathrm{r}=0.9)$, whereas this correlation was not significant for the intracellular microcystin production at the same period $(\mathrm{P} \geq 0.05, \mathrm{r}=0.7)$.

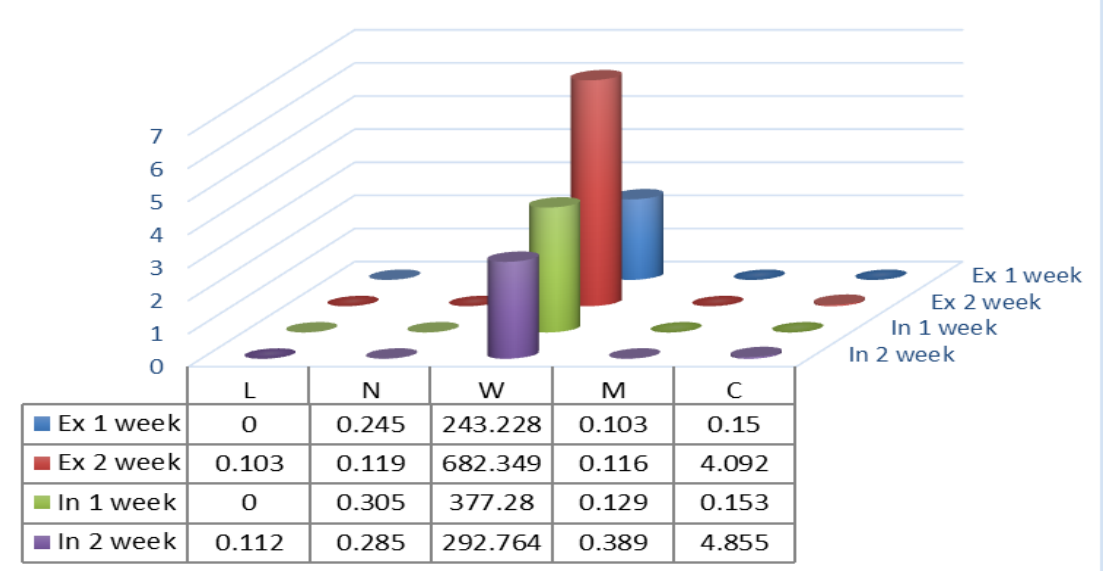

Figure 5. Quantification of microcystin production from the five cyanobacterial species in different time points $\left(1^{\text {st }}\right.$ and $2^{\text {nd }}$ week) by ELISA. Microcystin concentration was expressed as $\mathrm{ng} / \mathrm{ml} . \mathrm{L}=$ Lyngbya sp., $\mathrm{N}=N$. carneum, $\mathrm{W}=W$. prolifica, $\mathrm{M}=M$. aeruginosa, $\mathrm{C}=C$. turigidus. $\mathrm{Ext}=$ extracellular microcystin production and Int. $=$ intracellular microcystin production.

\section{Correlation between $m c y E$ gene and microcystin quantity}

The two methods (ELISA and qPCR) displayed good correlation $(\mathrm{P} \leq 0.05, \mathrm{r}=0.9)$ during the first week of growth with a decrease in correlation $(\mathrm{P} \geq 0.05, \mathrm{r}=0.6)$ in the second week.

$M$. aeruginoa, which has been extensively studied by researchers, is a very common bloomforming and important microcystin-producing species in freshwaters that exists all over the world. Data for $M$. aeruginosa were variable with significant microcystin expression detectable in the $3^{\text {rd }}$ week (Fig. 4), while microcystin production (both intracellular and extracellular) gave nonsignificant differences at the studied periods of time for the toxin production assay (Fig. 5). Results about microcystin production studies can sometimes be conflicting because experiments performed under laboratory conditions can differ from those performed in natural environments. In several studies (20, 24, 25), Microcystis sp. produced more microcystins within the time period due to some factors like an increase in cell density with time, limitations in nutrient availability and other reasons. As indicated by Wood et al. (26), vicissitude in microcystins levels characterized by intermittent production of microcystin (bouts of up- and downregulation in microcystin synthesis) could occur during time for some reasons such as changes in cyanobacterial cell density. Using a monoculture of M. aeruginosa, Ngwa et al. (27) reported continuous increase in microcystin concentration from day 5 to day 21 while mcyE expression witnessed periodic fluctuations (vicissitude in gene expression: up-and-down regulation) during this period. By the same token, a study by Beversdorf et al. (28) indicated that $m c y E$ abundance did not correlate with microcystin concentration. Thus, it is plausible to conclude that the lack of correlation seen sometimes between mcy expression and microcystin production could suggest that microcystin biosynthesis might be regulated post transcriptionally.

As for C. turigidus, N. carneum, and Lyngbya sp., although containing the microcystin gene $(m c y E)$ as demonstrated by the PCR assay, both $m c y E$ expression and microcystin production (intracellular and extracellular) were insignificant throughout all the studied periods of time. It is not surprising to see potentially toxigenic cyanobacteria (e.g., containing $m c y$ gene) with no notable expression/production of microcystin. Earlier studies $(29,30)$ demonstrated that potentially toxigenic cyanobacteria (containing mcygene) that did not produce microcystin can occur in natural environments. Several factors, among which nutrients, light, temperature, $\mathrm{pH}, \mathrm{CO} 2$, competition (e.g., grazing) were studied extensively that could overall affect microcystin production. Still, microcystin production is a very complex process and till now factors triggering its production and why production can be variable between species or genotypes of the same species are not fully understood (26). 
The alga $W$. prolifica is an understudied species in the literature especially in relation to microcystin production. Although Cirés et al. (22) studied Westiellopsis sp., neither mcy gene nor microcystin production was positive for Westiellopsis sp. Nonetheless, our previous work (10) showed the presence of $m c y E$ in $W$. prolifica but till this date, none reported the ability of this alga to produce microcystins in vitro. The result of this study is the first to confirm the in-vitro microcystin production by this species. In addition, it is found this alga, has a high toxigenic potential (i.e., high microcystin-producing ability) that surpassed other bloom-forming species in microcystin production and was the main producer of microcystin. It should be mentioned that the level of the microcystin produced by $W$. prolifica in our study in-vitro assays and under laboratory conditions exceeds the recommended WHO guideline level $(1 \mu \mathrm{g} / \mathrm{l})$ set for this toxin in freshwaters (31). Thus, Iraqi environmental and health authorities should periodically monitor microcystin production and its concentration in Iraqi freshwaters and take the required countermeasures. As $W$. prolifica demonstrated high microcystin-producing ability, it would be interesting to study the mcy genes in more detail in this species.

\section{Conclusions:}

This study is the first to clearly confirm the toxigenicity of $W$. prolifica by the production of $m c y E$ transcripts and secretion of microcystin in vitro by molecular and immunological assays. $W$. prolifica show a high microcystin-producing ability and could be considered as one of the main microcystin-producing cyanobacteria in Iraqi freshwaters.

\section{Acknowledgments}

The authors thank the American Academy Research Institute in Iraq (TARII) for funding our study. Also, we thank Dr. Muli for reviewing the manuscript.

\section{Conflicts of Interest: None.}

\section{References:}

1. Schmidt JR, Wilhelm SW, Boyer GL. The Fate of Microcystins in the environment and challenges for monitoring. Toxins (Basel). 2014 Dec.; 6(12): 33543387.

2. Rai AK, Chaturvedi R, Kumar A. Proteomic Evidences for microcystin-RR-induced toxicological alterations in mice liver. Sientific Reports. 2018 Dec; 8:1310-1324.
3. Dittmann E, Fewer DP, Neilan BA. Cyanobacterial toxins: biosynthetic routes and evolutionary roots. FEMS Microbiol. Rev.2013 Jan; 37:23-34.

4. Otten T.G., Parel H.W. Health effects of Cyanobacteria in U.S drinking water: our current understanding and proposed direction. Curr. Enviro. Rpt. 2015 Jan;2: 75-84.

5. Harke MJ, Steffen MM, Gobler CJ, Otten TG, Wilhelm SW, Wood SA, et al. A review of the global ecology, genomics, and biogeography of the toxic cyanobacterium, Microcystis spp. 2016 Apr. Harmful Algae; 45: 4-20.

6. Fathalli A, Jenhania ABR, Moreira C, Welker M, Romdhane M, Antunes A et al. Molecular and phylogenetic characterization of potentially toxic cyanobacteria in Tunisian freshwaters. Syst Appl Microbiol. 2011 Jun; 34: 303-310.

7. Mohammed MA, Ahmed SH, Amin AS, Ibrahim ZN, Hussein AA. Oxidative stress induced in mice by toxin of Oscillatoriabrevis (Kütz) collected from Suez freshwater Canal. Egypt J. Nat. Toxins. 2010 May; 8 (1, 2): 16-31.

8. Mohamed ZA, Al Shehri AM. Assessment of cylindrospermopsin toxin in an arid Saudi lake containing dense cyanobacterial bloom. Environ Monit Assess. 2013 Mar; 185: 2157-216.

9. Al-Shaheen MAG, Al-Sultan FBH. Isolation and identification of Oscillatoria tenuis var.natans Gomont from Iraq water and study of it is ability to produce toxins and their biological effects on laboratory mice. Bas.j.Vet.Res, 2011 Oct; 10 (2):1-20.

10. Abed IJ, Jawad AM, Abdulhasan GA, Al- Hussieny AA, MoushibL. Molecular detection of toxigenic new record cyanobacterium: Westiellopsis prolifica in Tigris River. Int. J Sci and Tech Res. 2013 Nov; 2(11):87-91.

11. AL-Sultan EYA, Abbas SS. Toxic effects of sublethal dose of algal toxin (Microcystin-LR) on male laboratory mice Mus muscullus L. Inter. J. Biosci, 2017 Nov; 11 (5):192-203.

12. Al-Sultan EYA, Hatem MT. Isolate and cultivate three species of blue-Green algae from soil southern of Iraq and study the effect of purified microcystins from alga Oscillatoria Pseudogeminata on seed germination of tomato plant Lycopersicon Esculentum. J. of Biology, Agriculture and Healthcare 2018; 8(16).

13. Stein J. Hand book of phycological methods. Cambridge Univ. Press. Cambridge, 1975. 445p.

14. Desikachary TV. Cyanophyta. New Delhi: Indian Council of Agricultural Research; 1959.

15. Matehkolaei A R, Makimura K, Shidfar M R, Zaini F, Eshraghian M R, Jalaizand, N, et al. Use of singleenzyme PCR-restriction digestion barcode targeting the internal transcribed spacers (ITS rDNA) to identify Dermatophyte Species. Iranian J. Publ. Health. 2012 Apr; 41(3): 82-94.

16. Jungblut AD, Neilan BA. Molecular Identification and evolution of the cyclic peptide hepatotoxins, microcystin and nodularinsynthetase genes in three orders of cyanobacteria. Arch. Microbiol.2006Mar; 185: 107-114. 
17. Sambrook J, Fritsch EF, Maniaties T. Molecular cloning, a laboratory manual, Cold Spring Harbor Laboratory Press, $2^{\text {nd }}$ edition, 1989.

18. Vaitomaa J, Rantala A, Halinen K, Rouhiainen L, Tallberg P, Mokelke L, et al. Quantitative Real-Time PCR for determination of sicrocystin Synthetase E copy numbers for Microcystis and Anabaena in lakes. Appl Environ Microbiol. 2003 Dec; 69 (12):72897297.

19. Lei LM, Wu YS, Gan NQ, Song LR. An ELISA-like time-resolved fluorescence immunoassay for microcystin detection. ClinChimActa. 2004 Oct; 348:177-180.

20. Fortin N, Aranda-Rodriguez R, Jing H, Pick F, Bird $\mathrm{D}$, Greer CW. Detection of microcystin-producing cyanobacteria in missiquoi Bay Quebec, Canada using quantative PCR. Appl. Environ. Microbiol. 2010 Aug;76(15):5105-5112.

21. Bukowska A, Kaliński T, Koper M, KostrzewskaSzlakowska I, Kwiatowski J, Mazur-Marzec, et al. Predicting blooms of toxic cyanobacteria in eutrophic lakes with diverse cyanobacterial communities. Sientific Reports. 2017 Dec; 7: 8342-8354.

22. Cirés S, Alvarez-Roa C, Wood SA, Puddick J, Loza,V, Heimann K. First report of microcystinproducing Fischerella sp. (Stigonematales, Cyanobacteria) in tropical Australia. Toxicon. 2014 Sep; 88:62-66.

23. Verma V, Malar M, Tripathy S. Comparitive genomics of Westiellopsisprolifica a freshwater cyanobacterioa uncovers the prolific and distinctive metabolic potentials. Can. J Biotech,.2017 Oct; 1: 123.

24. Burford MA, Davies WD, Orr PT, Sinha R, Willis A, Neilan BA. Nutrient related changes in the toxicity of field booms of the cyanobacterium, Cylindrospermopsis raciborskii. FEMS Microbiol. Ecol. 2014 Jul; 89(1): 135-148.

25. Pereira DA, Giani A. Cell density-dependent oligopeptide production in cyanobacterial strains. FEMS Microbiol Ecol. 2014 Apr; 88:175-183.

26. Wood SA, Rueckert A, Cary SC, Hamilton DP, Dietrich DR. Switching toxin production on and off: intermittent microcystin synthesis in a Microcystis bloom. Environ Microbiol Rep. 2011;3:118-124.

27. Ngwa FF, Chandra CA, Jabaji MS. Comparison of cyanobacterialmicrocystinsynthetase (mcy) E gene transcript levels, mcy E gene copies, and biomass as indicators of microcystin risk under laboratory and field conditions. Microbiol Open. 2014 May; 3: 411425.

28. Beversdorf LJ, Chaston SD, Miller TR, McMahon KD. MicrocystinmcyA and $m c y E$ gene abundances are not appropriate indicators of microcystin concentrations in lakes. PloS ONE [Internet]. 2015 May; 10:e0125353. Doi: 10.1371/journal.pone.0125353.

29. Christiansen G, Molitor C, Philmus B, Kurmayer R. Nontoxic strains of cyanobacteria are the result of major gene deletion events induced by a transposable element. MolBiolEvol. 2008 Sep; 25:1695-1704.

30. Ostermaier V, Kurmayer R. Distribution and abundance of nontoxic mutants of cyanobacteria in lakes of the Alps. Microb Ecol. 2009 Feb; 58:323333.

31. World Health Organization. Guidelines for safe recreational waters, Volume 1 - Coastal and fresh waters: Algae and cyanobacteria in fresh water. WHO Publishing, Geneva; 2003.Chapter 8; p.136-158.

$$
\begin{aligned}
& \text { طرق تقدير جزيئية ومناعية لتأكيد القابلية السمية (انتاج المايكروسستين) من طحلب } \\
& \text { المعزول من مياه نهر دجلة ــ العراق Westiellopsis prolifica }
\end{aligned}
$$

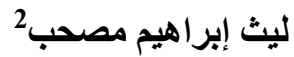

$$
\begin{aligned}
& \text { غصون علي عبد الحسن } \\
& \text { إبراهيم جابر عبد }
\end{aligned}
$$

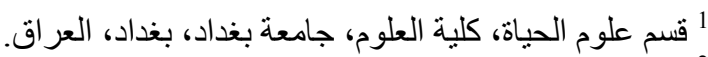

$$
\begin{aligned}
& \text { 2 قسم علوم الحياة، جامعة لوند، لوند، السويد. }
\end{aligned}
$$

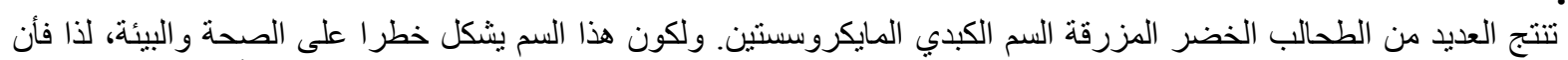

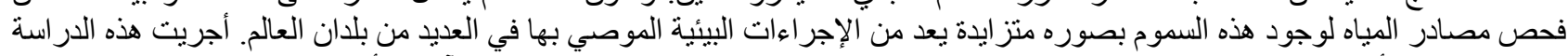

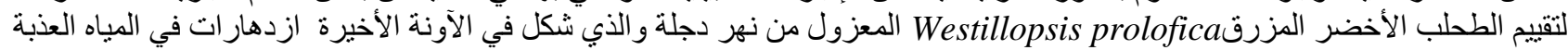

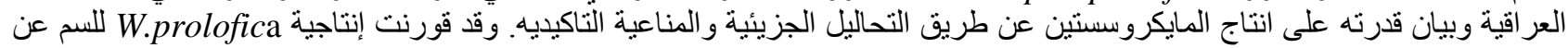

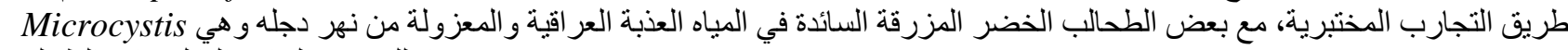
aeruginosa, Chroococcus turigidus, Nostoccarneum, and Lyngbya sp. W. الأخضر Microcystis aeruginosa

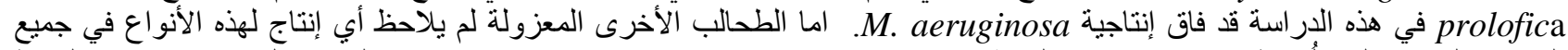

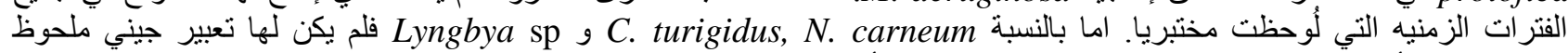

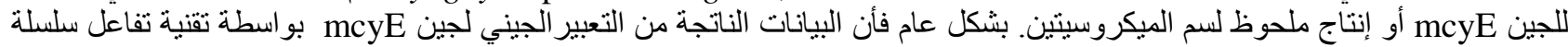

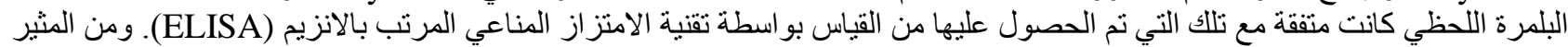

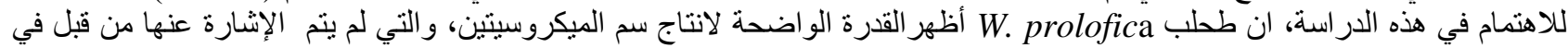

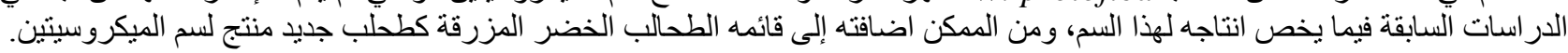

الكلمات المفتاحية: طحالب خضر مزرقة، Westillopsis prolofica، نهر دجلة، مايكروسستين و ELISA. 